\title{
Distribution of investment resources: where is agriculture in the Ukraine's economy?
}

\author{
Mykola Sokolov
}

Doctor of Economics, Professor, Vice-Rector, Sumy National Agrarian University, Ukraine

\section{Andrii Mykhailov}

Doctor of Economics, Associate Professor, Sumy National Agrarian University, Ukraine

\section{Dmytro Khandurin}

Master Student, Sumy National Agrarian University, Ukraine

\begin{abstract}
This article summarizes the arguments and counterarguments in the framework of the scientific discussion on the distribution of investment resources of the national economy of Ukraine and the definition of the place of the agricultural sector in it; highlighted indicators of Ukraine's economic development; compared, projected and indicated changes in the dynamics of GDP and capital investment; the results of profitability (loss-making) of branches of the national economy of Ukraine are presented.
\end{abstract}

The main objective of the study is to highlight the problems of the efficiency of the distribution of investment resources (capital investments) among the Ukrainian economy in the context of their economic efficiency. The systematization of literary sources and approaches to the solution of the problem of investment resource allocation has shown that in the world they are viewed as a form of capital transformation in a globalizing economic environment, providing an increase in gross added value, technology transfer, the creation of workplaces, the improvement of the competitiveness of industries and regions, and as a consequence - GDP's growth of the country. The urgency of solving this scientific problem lies in the fact that for the last 5 years the agrarian sector of Ukraine's economy is considered as a factor of macroeconomic growth, providing about $20 \%$ of GDP and almost $45 \%$ of foreign exchange earnings. The research of the distribution of investment resources of the national economy in the article is carried out in the following logical sequence: the indicators of economic development of Ukraine are highlighted, the dynamics of changes in Ukraine 's GDP and capital investments are presented, with the help of correlation - regression analysis, the forecasting for 2016-2019 of both indicators is carried out, the profitability of the economic activity of Ukrainian enterprises in terms of branches. The methodical tools of the conducted research were the methods of synthesis and analysis, comparison, correlation-regression, the period of the study is selected years 2002-2015, and for forecasting 20162019 years. The object of the study was selected - investment processes in the Ukrainian economy, since it they provide innovative and investment development of the economy and its growth. The article presents the results of an empirical analysis of the impact of capital investment on the country's GDP, which showed that their distribution is non-systemic and requires correction taking into account their resulting impact on more profitable branches and the agrarian sector, in particular. The study empirically confirms and theoretically proves that the innovation and investment development of the Ukrainian economy can be secured by directing investment resources into agricultural production with high added value.

JEL Classification: E22, F21, O13, O16

Key words: agriculture, agrarian sector, capital investments, development, economy, investment resources, gross domestic product, management, national economy, Ukraine.

(C) The Authors, 2018. This article is published with open access at Sumy State University.

\section{Introduction}

In the context of existing transformations, one of the key factors for acquiring the status of a full partner is the growing investment attractiveness of the country, which will enable it to become a participant in the world capital market through attracting foreign investment resources to the country, and, on the other hand, reduce the outflow of its own investment resources from the country.

Private investment is essential if agriculture is to fulfill its vital function of contributing to economic development, poverty reduction and food security. Agricultural production needs to increase by at least $60 \%$ over the next 40 years to meet the rising demand for food resulting from world population growth, higher income levels and lifestyle changes. Given the limited scope for net area expansion, agricultural growth will rely 
mainly on new increases in productivity, supported in particular by private investment in physical, human and knowledge capital. Agricultural investment is thus critical to expand agricultural production in a context of rising land and water scarcity. It can also bolster incomes and consumption in rural areas, thereby improving global food security through enhancing not only food availability but also access to food and food utilization (OECD 2014).

Main part. Investment resources are determining that one of the key factors of globalization (Mayorova T.V., Diba M.I., Onyshko S.V. 2012). In the opinion of these authors, globalization should be considered from the point of view of the process of world development, under the influence of which is the formation and establishment of an effective mechanism for the functioning of the world capital market, which is an investment resource. The most competitive struggle between influential international players is precisely the sphere of influence on the management of investment resources.

In the process of studying the structure of financing of capital investments, investment trends in terms of assets and types of economic activity, a number of destructive elements have been identified that have caused a slowdown in investment processes (Mykhailova L., Mykhailov A. 2017). In addition, the political and economic crisis of recent years greatly complicated the current situation by the actions of such negative factors as: inflation processes, exchange rate fluctuations of the national currency, growth of budgetary expenditures of social orientation, significant tax burden, lack of financial and credit mechanism, lack of coherence in the actions of the authorities, inconsistency in normative acts.

Taking into account the close connection between macroeconomic indicators and investments, one of the key tools for building a stable economic environment of the country in the context of globalization processes, financial and economic and political instability is the availability of sufficient financial support for capital investments. In this context, it is advisable to assess key indicators that characterize the possibility of identifying an internal reserve for the formation of financial support for capital investment, by examining the dynamics of the share of capital investment in gross domestic product (GDP).

Listed in Table 1 data indicate a significant deterioration in the financial providing, of capital investments during 2010-2015.

Table 1. Indicators of economic development in Ukraine, 2002-2015*

\begin{tabular}{|l|c|c|c|c|c|c|c|}
\hline \multirow{2}{*}{ Indicators } & \multicolumn{7}{c|}{ Years } \\
\cline { 2 - 8 } & $\mathbf{2 0 0 2}$ & $\mathbf{2 0 0 3}$ & $\mathbf{2 0 0 4}$ & $\mathbf{2 0 0 5}$ & $\mathbf{2 0 0 6}$ & $\mathbf{2 0 0 7}$ & $\mathbf{2 0 0 8}$ \\
\hline Gross domestic product, UAH million & 225810 & 267344 & 345113 & 441452 & 544153 & 720731 & 948056 \\
\hline Cost of fixed assets, UAH million & 964814 & 1026163 & 1141069 & 1276201 & 1568890 & 2047364 & 3149627 \\
\hline $\begin{array}{l}\text { Capital investment in economy, UAH } \\
\text { million }\end{array}$ & 46563 & 59899 & 89314 & 111174 & 148972 & 222679 & 272074 \\
\hline Share of capital investments in GDP,\% & 20.6 & 22.4 & 25.9 & 25.2 & 27.4 & 30.9 & 28.7 \\
\hline $\begin{array}{l}\text { Share of capital investments in the total } \\
\text { value of fixed assets, \% }\end{array}$ & 4.8 & 5.8 & 7.8 & 8.7 & 9.5 & 10.9 & 8.6 \\
\hline & $\mathbf{2 0 0 9}$ & $\mathbf{2 0 1 0} *$ & $\mathbf{2 0 1 1}$ & $\mathbf{2 0 1 2}$ & $\mathbf{2 0 1 3}$ & $\mathbf{2 0 1 4}$ & $\mathbf{2 0 1 5}$ \\
\hline Gross domestic product, UAH million & 913345 & 1079346 & 1299991 & 1404669 & 1465198 & 1586915 & 1988544 \\
\hline Cost of fixed assets, UAH million & 3903714 & 6648861 & 7396952 & 9148017 & 10401324 & 13752117 & 7641357 \\
\hline $\begin{array}{l}\text { Capital investment in economy, UAH } \\
\text { million }\end{array}$ & 192878 & 189061 & 259932 & 293692 & 267728 & 219420 & 273116 \\
\hline Share of capital investments in GDP,\% & 21.1 & 17.5 & 20.0 & 20.9 & 18.3 & 13.8 & 13.7 \\
\hline $\begin{array}{l}\text { Share of capital investments in the total } \\
\text { value of fixed assets,\% }\end{array}$ & 4.9 & 2.8 & 3.5 & 3.2 & 2.6 & 1.6 & 3.6 \\
\hline
\end{tabular}

* the indicators for 2010-2015 are calculated without taking into account the temporarily occupied territory of the Autonomous Republic of Crimea and the city of Sevastopol

Source: formed and calculated according to the data of the State Statistics Committee of Ukraine.

Negative dynamics in reducing the share of capital investments in GDP bear not only obvious effects, but also constitute an obstacle to becoming on the European path of development, since it is mandatory for implementation member states of the European Union is investing in fixed assets not less than $30 \%$ of national GDP (Lanovoy V. 2011).

Taking into account the indicators of 2006-2008, fulfillment of this condition for Ukraine was quite achievable; however, considering the indicators of 2013-2015, reaching the level of $30 \%$ is possible even if the vol- 
ume of capital investments is more than doubled. In addition, the critically low proportion of capital investment in the total value of fixed assets (less than 5\%) raises the question of the availability of an investment resource for the modernization of production and its innovation development.

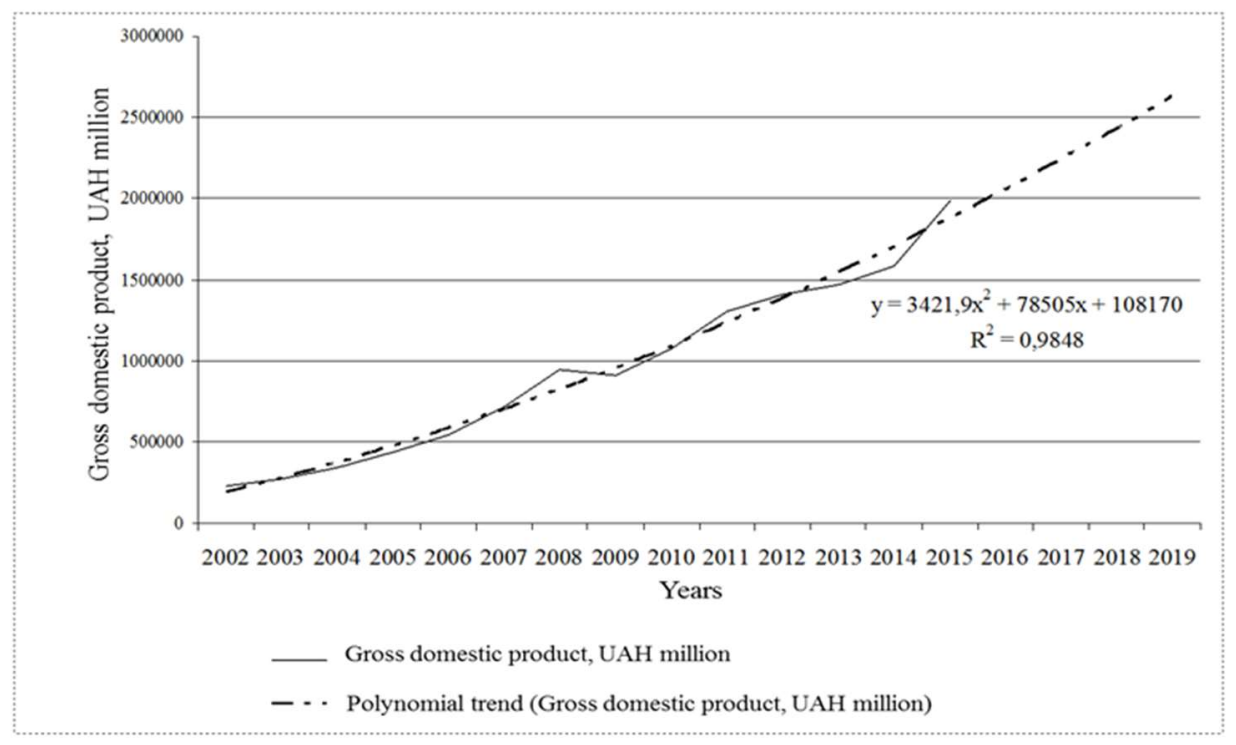

Figure 1. Dynamics of GDP of Ukraine, 2002-2019 (predicted values for 2016-2019), UAH million.

Source: formed and calculated according to the data of the State Statistics Committee of Ukraine.

We will investigate the prospect of increasing the share of capital investment in gross domestic product, using graphical tools of regression analysis. It is substantiated that the effect of the main factors on a certain indicator during the time series is accumulated and can be expressed by the level of the trend and presented graphically. Using trends to determine the dynamics of Ukraine's gross domestic product and capital investment in the Ukrainian economy for the period from 2002 to 2015, structuring the reflection of changes in data and expanding the possibility of analysis for the implementation of the forecast.

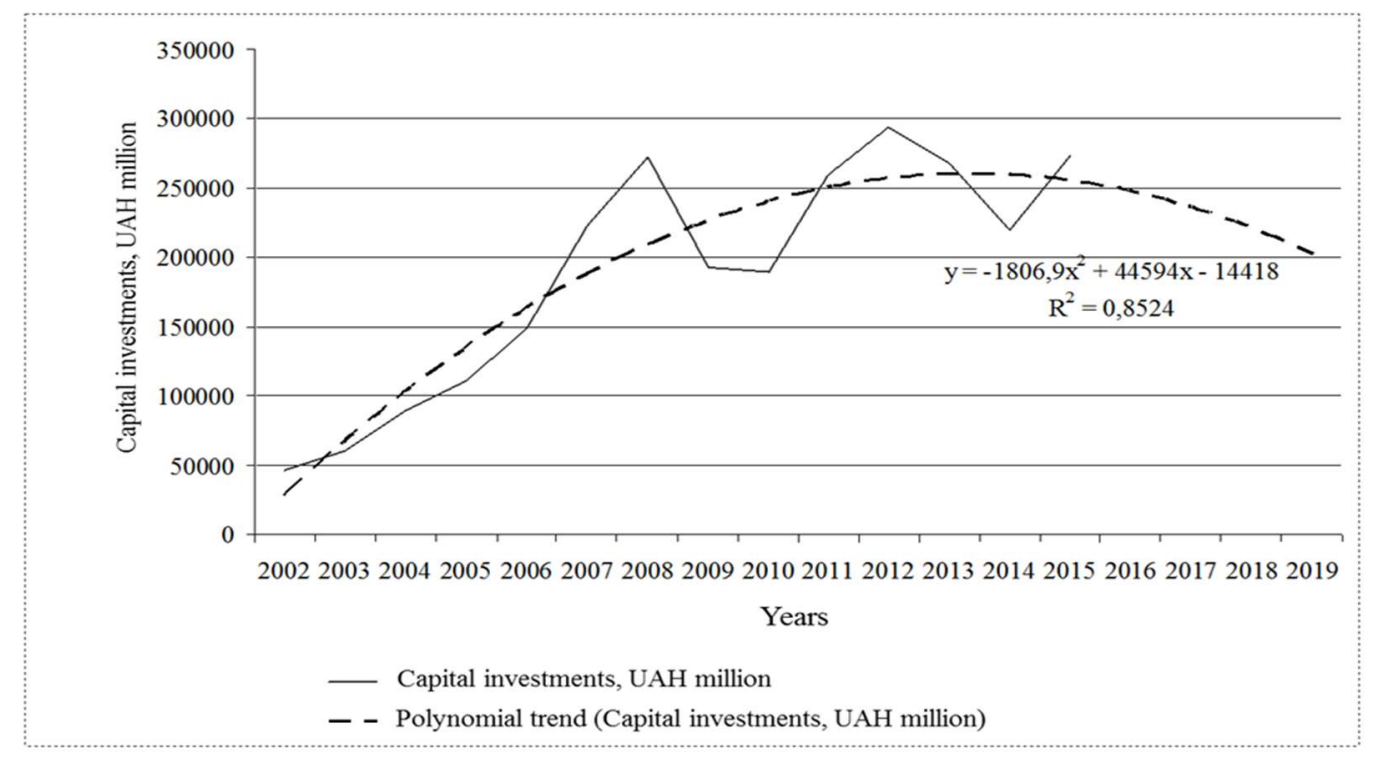

Figure 2. Dynamics of capital investments into the economy of Ukraine, 2012-2019 (predicted values for 2016-2019), UAH million. Source: formed and calculated according to the data of the State Statistics Committee of Ukraine.

Figure 1 and Figure 2 show the dynamics of the actual data of the gross domestic product and capital investments for the period from 2002 to 2015 and calculated the predicted values of the studied indicators for the period from 2016 to 2019 (for the reliability of the data the forecast is made by one-third of the investigated interval).

The main criterion for choosing the type of equation, as a rule, is the determination coefficient. The most appropriate models of the trends of the gross domestic product and capital investments were the polynomial 
second degree; the quality of the constructed polynomial regression models was reasoned by the calculated determination coefficients of 0.9848 and 0.88524 , respectively.

It is quite evident that the growth of the gross domestic product trend (Figure 1) is evident, which confirms a steady tendency to increase by the given indicator during the investigated period. As a function of the time trend function, which is shown in the diagram, the projected growth of gross domestic product for the next four years is evident. Therefore, in order to form a positive tendency towards the ratio of capital investments to gross domestic product, the trend of capital investment should, at a minimum, reflect a similar trend. As can be seen from Fig. 2, the trend of capital investment reflects the opposite trend, indicating a projected decline in capital investment in the short term and a further decrease in the share of capital investment in GDP. In addition, the different trends of GDP trends and capital investments indicate a lack of significant correlation between indicators.

The profitability of operating activities of enterprises operating in all branches of the national economy during 2010-2015 is presented in Table 2.

Table 2. Profitability of operating activity of enterprises by types of economic activity, 2010-2015*

\begin{tabular}{|c|l|c|c|c|c|c|c|}
\hline \multirow{2}{*}{ № } & \multicolumn{1}{|c|}{ Types of economic activity } & \multicolumn{5}{|c|}{ Profitability level (loss-making), \% } \\
\cline { 3 - 7 } & \multicolumn{2}{|c|}{2010} & 2011 & 2012 & 2013 & 2014 & 2015 \\
\hline Total: & 4.0 & 5.9 & 5.0 & 3.9 & -4.1 & 1.0 \\
\hline 1 & Including: & & & & & & \\
\hline 2 & Agriculture. Hunting. Forestry & 23.2 & 23.6 & 21.7 & 11.3 & 20.6 & 41.7 \\
\hline 3 & Industry & 3.6 & 4.7 & 3.4 & 3.0 & 1.6 & 0.9 \\
\hline 4 & Construction & -1.2 & 0.8 & -0.1 & 0.0 & 5.8 & -7.6 \\
\hline 5 & $\begin{array}{l}\text { Trade; Repair Of Cars. Household Products And Personal } \\
\text { Items }\end{array}$ & 9.8 & 15.0 & 12.2 & 10.2 & -12.8 & -0.9 \\
\hline 6 & The Activity Of Hotels And Restaurants & -1.8 & -0.1 & -2.9 & -2.5 & -13.6 & -11.9 \\
\hline 7 & Transport And Communications Activities & 7.2 & 7.5 & 5.4 & 3.5 & -1.7 & 1.1 \\
\hline 8 & Financial Activity & 3.2 & 6.3 & 6.1 & 5.9 & -15.2 & -8.9 \\
\hline 9 & $\begin{array}{l}\text { Real Estate Operations. Leasing. Engineering And Services To } \\
\text { Entrepreneurs }\end{array}$ & -4.2 & -0.7 & 2.8 & 3.1 & -46.9 & -33.4 \\
\hline 10 & Education & 6.7 & 8.6 & 8.2 & 8.4 & 5.5 & 5.7 \\
\hline 11 & Health Care And Social Assistance & 3.9 & 2.7 & 2.7 & 3.1 & -3.7 & -0.6 \\
\hline 12 & $\begin{array}{l}\text { Provision Of Communal And Individual Services; Cultural } \\
\text { And Sporting Activities }\end{array}$ & -14.8 & -13.8 & -17.6 & -8.0 & -11.8 & -25.3 \\
\hline
\end{tabular}

* Data for the period 2010-2015 are given without taking into account the performance of banks, budget institutions and data for 2014-2015, do not include the results of the activity of the temporarily occupied territory of the Autonomous Republic of Crimea, the city of Sevastopol and parts of the zone of anti-terrorist operation.

Source: formed and calculated according to the data of the State Statistics Committee of Ukraine

Negative dynamics of the trend of capital investment is due to a decline in resource opportunities for the accumulation of capital due to factors such as: falling production, depreciation of fixed assets, unemployment in the economy, investing in the non-profit sectors of the national economy, reducing financial investment (including foreign), in the economy, etc.

The results of the study have argued the priority of the introduction of measures, mechanisms, economic instruments to increase capital investments into the economy of Ukraine. There is a completely different tendency towards investing in agriculture, as growth of capital investments in 2015 compared with 2014 by $60.4 \%$ ensured an increase in the profitability of agriculture twice and amounted to $41.7 \%$. At the same time, the volume of capital investments in construction sector at 2015 exceeded 1.5 times higher, than investment in agriculture, but production in this type of economic activity was loss-making (-7.6\%). The investigated trend point to the lack of a reasonable approach to the distribution of capital investments (Mykhailov A. 2016), taking into account the profitability of economic activities, and confirms the sustainability of the tendency to send capital investments to low-yielding fixed assets.

In confirmation of the importance of improving the investment mechanism in force in Ukraine, it is expedient to bring the results of correlation-regression analysis (Pirog O. 2013) on the impact of investments on the country's economic growth. Thus, an increase in investment in fixed assets by $1 \%$ stimulated the growth of the national economy by only $0.3395 \%$. The author argues that investments are not crucial for the economic 
development of the national economy because of the chaos of capital investment and the lack of sustainability of investment in terms of industries.

\section{Conclusion}

The research we conducted on the development of investment activity is convincing that it is foreign investments that can provide for correction of existing inter-branch disproportions. Summing up, it should be noted that the limited investment resources require their rational distribution in terms of both the components of material resources and between tangible and intangible assets, based on the strategic directions of development of the national economy.

However, it should be noted that this process is multidirectional, difficult to structure and requires a wellbalanced and well-grounded action plan, both at the state and regional levels, because effective management activity is a guarantee of the development of investment activity of the regional branches and the national economy of the country.

Analyzing the state of formation and directing of capital investments into the Ukrainian economy in the conditions of globalization, it should be noted that during the period of 2002-2015, the desired effect from invested capital investments was not achieved. It is argued that constructive changes in the accumulation and effective allocation of investment resources can be achieved in case of correction of existing approaches and the existing mechanism. Most imported and adopted directions to investments in Ukrainian economy could by: institutional projects to consolidate the interests of all stakeholders in agrarian relations to maximize the growth of gross value added, infrastructure projects (roads, ports, elevators, logistics centres) to increase export potential of the country, intersectoral research and digitalization of the economy sectors to increase the science-intensive and capital-intensive shares of the economy.

\section{References:}

1. Lanovoy V. (2011). Kapitalni vyklyky: ukrainska ekonomika pryrechena na kryzy [Capital challenges: the Ukrainian economy is doomed to crises], Ukrainian Week, 39 (204), 28-31. [In Ukrainian].

2. Majorova, T. (2012). Aktyvizatsiia investytsiinoho protsessu v Ukraini : kolekt. monohrafiia (T. V. Maiorova, M. I. Dyba, S. V. Onyshkotain.) ; nauk. red. M. I. Dyby, T. V. Maiorovoi ; Ministerstvo osvity i nauky, molodi ta sportu Ukrainy ; DVNZ "Kyiv Natstsionalnyi Ekonomichnyi Universytet im. Vadyma Hetmana" [Activation of the investment process in Ukraine, collective monograph (T. Majorova, M. Diba, C. Onishko and other); by the science editorial board T. Majorova, M. Diba; Ministry of Education and Science, Youth and Sports of Ukraine ; State University "Kyiv National Economic University named after Vadym Hetman"], Kyiv: KNEU, 472 p. [In Ukrainian].

3. Mykhailov A.(2016). Metodychni pidkhody ta systema pokaznykiv vyznachennia investytsiinoho klimatu $\mathrm{v}$ ahrarnomu sektori ekonomiky [Methodological approaches and a system of indicators for determining the investment climate in the agrarian sector], The Economy of Agro-Industrial Complex, 12, 76-83. Available at: http://eapk.org.ua/contents/2016/12/76 on date 07.07.2017. [In Ukrainian].

4. Mykhailova L., Mykhailov A. (2017). Rehionalni aspekty formuvannia investytsii v ahrarnomu sektori //Materialy Mizhnarodnoi naukovo-praktychnoi konferentsii «Menedzhment KhKhI stolittia: hlobalizatsiini vyklyky»: zbirnyk naukovykh prats [Regional aspects of investment in the agrarian sector, Materials of the International Scientific and Practical Conference "Management of the XXI Century: Globalization Challenges": collective scientific works], Simon Publishing House, 80-83. [In Ukrainian].

5. OECD., Policy Framework for Investment in Agriculture, OECD Publishing 2014. Available at: http://dx.doi.org/10.1787/9789264212725-en on date 22.09.2017.

6. Pirog O. (2013). Tendentsii investuvannia natsionalnoho hospodarstva [Trends in investing in the national economy], Bulletin of the National University "Lviv Polytechnic", series "Management and Entrepreneurship in Ukraine: Stages of Development and Development Problems", 767, 343-349. [In Ukrainian].

7. Derzhavna sluzhba statystyky Ukrainy. (2017) [State statistical service of Ukraine]. Available from: http://www.ukrstat.gov.ua [In Ukrainian]. 